\title{
ASSESSMENT OF THE COMPOSITION OF SOME PERSONAL HYGIENE (ON THE EXAMPLE OF SHAMPOOS) REGARDING THE NEGATIVE EFFECT ON THE HUMAN BODY
}

\author{
N. Grabko \\ Senior Lecturer \\ Odesa State Environmental University \\ (Odesa, Ukraine) \\ e-mail: grabkonatalyavikt@gmail.com; \\ ORCID: https://orcid.org/0000-0003-1412-5683 \\ G. Vovkodav \\ Candidate of Chemical Sciences, Assistant Professor \\ Odesa State Environmental University \\ (Odesa, Ukraine) \\ e-mail: galinakoltykova258@gmail.com; \\ ORCID: https://orcid.org/0000-0002-4953-9491 \\ A.-V. Krutiy \\ Master \\ Odesa State Environmental University \\ (Odesa, Ukraine) \\ e-mail: violettakru9@gmail.com; \\ ORCID: https://orcid.org/0000-0002-2740-5281
}

All shampoos contain various harmful components that accumulate in the body, which can harm human health in general. They can cause allergies, provoke aging, lead to nervous disorders and cardiovascular disease. But, despite this, these substances can not be excluded from the composition of modern shampoos, as without this cosmetics will lose their properties. Choosing the right shampoo will help reduce the risk of harmful effects, but you need to know how it can adversely affect the health of an ingredient. The result is the recommended lists of specific shampoos that take into account all these aspects. Consumers who care about their health should be directly interested in such lists.

The aim is to identify the safest groups of shampoos in terms of their content of substances dangerous to human health. The object of personal hygiene products is shampoos (25 items). The subject of the study is the description of the safest groups of shampoos for consumers, taking into account their price and subjective assessment of consumers. The initial data was information about the composition of each of the shampoos and toilet soaps, specified by the manufacturer on the product packaging of each tested hygienic product. During the study, comparative-descriptive, graphical, and statistical (method of K-means cluster analysis) methods of processing and providing information were used. The results of the work are of direct practical importance, as they represent a direct recommendation for the consumer, which is the need to choose personal hygiene products (shampoo) among the proposed lists of the safest samples with the lowest price and best consumer properties.

Keywords: shampoo, sulfates, preservatives, parabens, phthalates, allergens.

\section{INTRODUCTION}

It is worth noting that indicators such as the price of the tool and its evaluation by the consumer are highly subjective. However, they are very important in terms of the choice of a particular product by the consumer. These two indicators are to some extent are a reflection of the consumer quality of the product for the consumer.

As for the price of the product, the consumer, on the one hand, does not want to buy too cheap, and therefore «a bad quality» product, and on the other hand - can not pay extra money.

As for consumer assessment, a large number of women want to rely on the opinion of those who have already tried this tool and, thus, to get an idea of its quality before buying. The low rating of a product indicates that it is unlikely that a large number of consumers would want to take risks and «waste the money» [1-4].

The aim is to identify the safest groups of shampoos in terms of their content of substances dangerous to human health. 
The subject of the study is the possibility of harmful effects of these personal hygiene products on human health.

The following tasks were set in the work: to analyze the composition of personal hygiene products; to identify in the composition of each product the substances that have or may have a certain harmful effect on the human body at the present stage of public awareness; summarize information about hazardous substances in each shampoo; determine the total amount of harmful substances in the composition of these hygiene products; determine the most desirable for consumption names of shampoos from the consumer's point of view using the methods of mathematical statistics.

\section{ANALYSIS OF RECENT RESEARCH AND PUBLICATIONS}

It should be noted that in our country cosmetics are not legally separated into a separate independent industry. At the same time, various scientists, within their scientific interests, study only certain aspects, choosing cosmetic products as the subject of their research. In particular, Bukreeva N.P. worked on accounting and control aspects of the use of imported raw materials in the perfume and cosmetics industry in the economic direction [5]. Gorodetskaya I.V. studied the features of English-language labeling of cosmetics within the specifics of philological sciences [6]. Such studies are necessary, but they are more aimed at making a practical contribution to the development of the sciences within which they were conducted. A number of medical and pharmaceutical scientists deal with the technology of perfumes and cosmetics. Among them: Bashura O.G., Tinonov O.I., Petrovska L.S., Kozakova V.S., Fedotov V.P., Gudz O.E.

All shampoos contain various harmful components that can harm human health in general. Analysis of publications [1-4] shows that they can cause allergies, provoke aging, lead to nervous disorders and cardiovascular disease. But, despite this, these substances can not be excluded from the composition of modern shampoos, because without them, cosmetics will lose their properties. Especially since the human body is able to self-cleanse, and health problems usually begin when the immune system is disrupted.

Choosing the right shampoo will help reduce the risk of harm, but you need to know how it can adversely affect the health of an ingredient.

After analyzing the technology of creating recipes for various cosmetics based on the works of well-known specialists in the cosmetics industry $[1-4 ; 7-9]$, it is concluded that from the whole set of factors that form the final quality, from the consumer's point of view, one of the most important is the planning and development of components content [10].

Production on the basis of artificial compounds occupies a significant part of the world market, is in a more affordable price segment for the consumer. Although the standardization of chemical compounds is regulated in the State Sanitary Norms and Rules, the chemical composition of cosmetics is difficult to study and analyze due to a number of components, the complexity of chemical processes, the obsolescence of test methods and devices. It should be noted that the production has significantly improved and new components are introduced into the recipes without proper regulatory argumentation at the state level [11-14].

\section{MATERIALS AND RESEARCH METHODS}

During the study, a group of personal care products such as shampoos was selected as the object of study. The information on 25 names of shampoos made by different manufacturers was investigated in the work. The source of initial data for the analysis was information about the composition of these funds, provided by the manufacturer on the product packaging.

A database was compiled, which contained such information as: trademark, product name, list of all ingredients in this product, price and consumer assessment of the quality of the tool on the basis of Internet resources (sites makeup. com.ua, parfums.ua, rozetka .com.ua).

The study was accompanied by extensive use of analytical and comparative methods. The authors themselves divided the shampoos into groups taking into account their characteristics (properties), such as price, consumer assessment and the number of dangerous ingredients. Relevant calculations were performed by the authors using a variety of multidimensional statistical methods, such as the method of cluster analysis (namely, the method of K-means), which allowed to characterize the average values in each selected group (cluster) of shampoos for each of these three properties. To visualize the obtained results, the method of graphical presentation of information was used.

\section{RESULTS AND THEIR DISCUSSION}

Shampoos are alcohol-water or aqueous solutions, gels or emulsions of surfactants with various useful additives and perfume fragrance [1-3].

Shampoos can be on a natural (soap) basis and on the basis of synthetic surfactants.

Modern shampoos are often products based on a mixture of synthetic surfactants of complex action, which perform several functions: basic 
(removal of impurities from the surface of the hair and scalp) and additional (nutrition, restoration, hydration, protection, hair coloring, etc.).

The composition of shampoos can be noted that surfactants are the basis of any shampoo and play the role of detergents, cleansers and foam components.

The most common surfactant in the recipes of modern shampoos - oxyethylated sodium lauryl sulfate or sodium laureth sulfate. Baby shampoos mainly use mild surfactants (c-surfactants), which are products based on the hydrolyzate of protein and fatty acids, such as coconut oil. This product is very suitable for creating transparent shampoos [1-4].

Thickeners, antistatics, preservatives, $\mathrm{pH}$ regulators, complexing agents, dyes, etc. are used as auxiliary raw materials.

Fatty additives are mainly fats and oils of natural origin. These include lanolin and its derivatives, almond, coconut, apricot, olive, sesame and other oils.

They are used to restore the lipid layer, ie to reduce the degreasing effect of the shampoo on the scalp and hair. This is especially true of shampoos to care for dry and damaged hair. These additives give the hair elasticity, shine and improve the appearance.

An important role in the composition of shampoos is played by biologically active additives (Dietary supplements): vitamins, plant extracts, algae extracts, fruit acids, etc., which promote cell renewal, improve hair structure, etc., as well as anti-dandruff supplements.

The most common ingredients are: Zinc Pynthione, Climbazole, Ketoconozole, Sulfur, Salicylic Acid, Octopirox, Piroctone Olamine (octopylax), Selenium Disulphide.

According to the principle of action, these substances can be combined into the following groups [4; 7]:

- conditioning additives. They are introduced into modern shampoos to achieve the following goals: removal of static electricity; smoothing and repairing damaged areas of hair rods; easy combing of wet and dry hair; minimization of porosity; giving hair some shine and silkiness; providing protection against thermal and mechanical damage; increase in volume and weight.

Conditioners include various oils, fatty alcohols, glycol esters, wetting agents and protein derivatives, as well as silicone compounds;

- thickeners (viscosity regulators). They are added to the shampoo to give the desired consistency, usually to increase viscosity. Sodium chloride $\mathrm{NaCl}$ is often used as a thickener for shampoos based on sodium lauryl sulfate [4; 7];
- emulsifiers make it possible to obtain a stable homogeneous emulsion and determine many important qualities of the shampoo: stability, consistency, homogeneity. As emulsifiers use surfactants, derivatives of fatty acids (lecithin, phospholipids), fatty alcohols, emulsion waxes, mixtures of esters of stearin, olein and polyethylene glycol (PEG-400), etc.;

- preservatives - special antimicrobial substances introduced into the composition of cosmetic products in order to ensure the storage of the cosmetic product and its safety for consumers during the warranty period.

The most commonly used preservatives: methylparaben, propylparaben, ethylparaben, propylparaben, bronopol, etc .;

- pH regulators. Soft acids (citric, lactic, orthophosphoric) or alkali (sodium hydroxide, mono- or triethanolamine) are added to correct the hydrogen index;

- fragrances. The fragrance is a complex mixture of synthetic and natural compositions, which is added to the shampoo in order to hide the unpleasant odor of the basic components and complete the aesthetic design. Synthetic and natural fragrances are used (plant extracts, essential oils, etc.) [4; 7];

- opalescent additives and opacifiers. Opalescent additives are used to impart opalescence to clear shampoos. They are usually waxy products, slightly soluble, but easily dispersed in shampoos. When selecting them, the main attention is paid to ensure that their use does not impair other important properties of the shampoo, in particular foaming. Foamers make it possible to give shampoos a uniformly turbid appearance. They mask the visual heterogeneities of the product, allowing it to give it new consumer properties;

- dyes are introduced in order to create a complete «product image» or to mask unwanted shades. Dyes must be safe for consumers, so cosmetic products use substances permitted by Directive 76/768 / EEC on the harmonization of the laws of the Member States relating to cosmetic products (as amended by Directive 2003 / EEC of 6 January 2003)., they must be resistant to light and must not interact with the components of the shampoo and packaging.

Recipes for baby shampoos are developed most carefully. They contain special mild surfactants, do not have a strong irritant effect, do not irritate the mucous membrane of the eye. As supplements contain large fatty substances, vitamins and plant extracts. To avoid allergic reactions, less shampoos and fragrances, conditioning additives are added to baby shampoos. The $\mathrm{pH}$ of baby shampoos should be neutral. Packaging of 
shampoos for children is often made in the form of a toy [4; 7-11].

According to the concentration of surfactants, shampoos are divided into regular and concentrated. $25 \%$ :

The surfactant content in shampoos is $5^{-}$

- in liquids $-5-20 \%$;

- in jelly-like $-5-24 \%$;

- in creamy - 10-20\%.

Shampoos with a mass fraction of surfactants from 16 to $25 \%$ are considered concentrated. Before use, such shampoos must be diluted with water.

In a quality surfactant shampoo should be at least $10-16 \%$. If shampoos contain $2-4 \%$ surfactants, it is difficult to wash your head with them.

Shampoos differ in frequency of use (for periodic and frequent (daily) use), type of packaging, countries and manufacturers, names, etc. [1; 3-4; 7-9].

In the range of shampoos a special place is occupied by medical (therapeutic) shampoos. These shampoos are manufactured by pharmaceutical companies. These are cosmetics that have healing properties. They must undergo dermatological tests and clinical trials and are sold through pharmacies. They are used after consultation and under the supervision of specialists (dermatologists). For example, the course of treatment with medical shampoo involves its use twice a week and is $3-4$ weeks (treatment of dandruff and seborrheic dermatitis), 6-8 weeks (for thinning hair), 8-12 weeks (treatment of psoriasis of the scalp).

Shampoos are available both individually and in series of hair care products $[1 ; 3-4 ; 7-9]$.

After analyzing the composition of 25 personal care products, it was found that the shampoos contain a large number of hazardous substances that belong to such groups as detergents, preservatives, polymers, fragrances and others.

When considering shampoos, first of all you should pay attention to detergents, which are a mandatory component of any shampoo.

The most dangerous - lauryl ammonium sulfate and laureth ammonium sulfate - are absent in the studied shampoos. But the three most dangerous carcinogenic detergents are closed by sodium lauryl sulfate, which is found in 2 shampoos (Aasha Ayurvedic shampoo for colored hair and in the shower gel shampoo 2 in 1 «Ice» Old Spice).

Sodium laureth sulfate, which is considered safer, is found in 18 types of shampoos. However, greater safety means that the chemical com- position of this component allows it to enter the bloodstream through the pores of the skin and accumulate in the tissues of the liver, heart and eyes. It is a toxic mutagen that can disrupt metabolic processes. Quality shampoos do not contain this substance.

And lauryl sulfate TEA and laureth sulfate TEA, which should be present in quality shampoos, are absent in all of the studied.

Other shampoos contain detergents, the dangerous effects of which on the human body have not been found.

The studied shampoos contain 2 preservatives: methylparaben (in the shampoo for dry and dead hair Syoss) and phenoxyethanol (in the shampoos of Shakylab, Clear Vita Abe, L'Oreal Paris Elseve, Garnier, Brelil, Syoss).

Parabens are preservatives that can inhibit the growth of microorganisms. They are substances that can cause allergies. Accumulating in the tissues, they can lead to hormonal imbalance and the development of malignant tumors. Phenoxyethanol is characterized by the ability to cause allergies and has a destructive effect on the endocrine system.

Dimethicone silicone is found in Shakylab, L'Oreal Paris Elseve, Aasha, Amway, Gliss Kur shampoos. Silicones have a detrimental effect on problem skin. They clog pores and promote the formation of microcysts, blackheads and pimples. In addition, silicones prevent any other means of penetrating the skin. Prolonged use of hair products containing silicones leads to the fact that the hair becomes greasy and heavy. The positive effect of silicones is that they can create a barrier that prevents the penetration of harmful substances into the skin, such as dirt. However, the skin gets used to this barrier.

Among the studied shampoos, 5 dyes were found. Only Cl 77491 (or iron oxide) is safe among them. It is a substance of natural origin that does not cause harmful effects if the established requirements are met. Another substance of natural origin is $\mathrm{Cl} 77891$ (titanium dioxide), which has long been considered safe and widely recommended for use and even used as a dietary supplement, but recently there has been enough information about its harmful effects (may accumulate in the intestines, liver, lungs, brain and can contribute to cancer).

Another 3 substances - of synthetic origin and capable of toxic, allergenic, and in the case of Cl 17200 - both types of negative effects on the human body [1;3-4; 7-9].

To give a pleasant aroma to shampoos, socalled fragrances are used, which can be of natural or synthetic origin. Natural substances are 
listed as essential oils of the respective plants, and fragrances of synthetic origin are labeled on the package as Parfum (or Fragrance) and have properties similar to parabens. Among the studied shampoos, 20 out of 25 have the mark Parfum (or Fragrance), which indicates the artificial origin of their fragrance.

Another group of substances that have been found in shampoos are allergens. These included Alpha-isomethyl Ionone, Amyl Cinnamal, Benzyl Alcohol, Benzyl Salicylate, Butylphenyl Methylpropional, Citronellol, Coumarin, Eugenol, Geraniol, Hexyl Cinnamal, Hydroxycitronellal, Limonene, Linalool, Methylisothiaz. These substances in one or different combinations were present in 18 of the 25 shampoos studied. In this case, these are substances that must be declared on the package, if their content exceeds $0.001 \%$ in non-rinsing products, or $0.01 \%$ - in all others. In fact, there are many more such allergens. It should also be noted that 1 previously mentioned preservative and 2 dyes also had an allergenic effect.

To summarize all this information, 1 to 13 substances dangerous to human health were found in various shampoos. Only one of the shampoo-conditioner for hair restoration with wheat proteins and essential oils of the "Yaka» brand did not reveal any of them.

It is quite difficult to identify the relationship between price, consumer assessment and the amount of harmful substances in the shampoo (this is also a fairly conditional characteristic of its quality, but more objective). But the con-

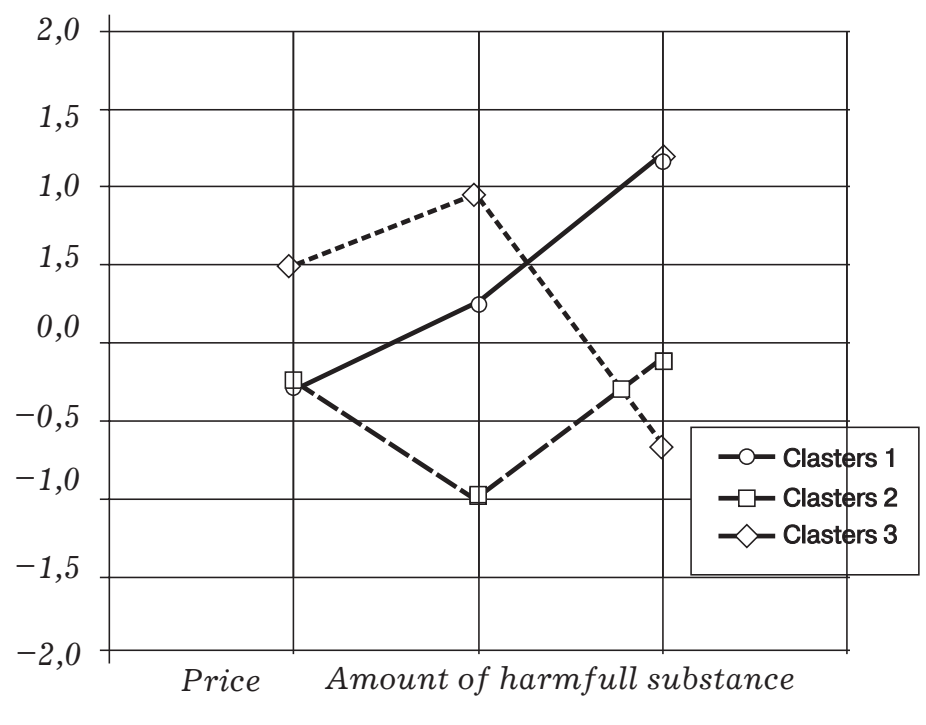

Consumer assessment

Fig. 1. The results of clustering of shampoos by three characteristics

Source: developed by the authors based on their own research. sumer must choose one of them for his own use. To address this issue, a cluster analysis of these 25 shampoos was performed.

As a result of cluster analysis, shampoos were divided into 3 groups-clusters, which differ from each other in three characteristics taken into account during the statistical analysis, namely: price, consumer ratings and the content of substances dangerous to humans.

The results of the cluster analysis are presented in Figure 1, which contains a graph of the averages for each of the three indicators (price, assessment, number of hazardous substances) in each of the three selected clusters. The red line combines the average values of cluster 1 , which includes shampoos that are least desirable for consumption, because they are characterized by the highest number of substances dangerous to human health.

Cluster 1 contains 6 shampoos, which are characterized by a price slightly below the average level, slightly above the average level by consumer estimates and a very high number of substances dangerous to the human body in the composition. Therefore, they should not be used by those who care about their health. These shampoos include the following: Estel Professional, mineral hair shampoo; L Oreal Paris, shampoo for long and damaged hair; L'Oreal Paris, dry shampoo «Explosion of freshness»; Garnier, Ginger Recovery Shampoo for exhausted and very thin hair; "Clean Line», hair shampoo "Strengthening»; Old Spise, shampoo-gel for shower 2 in 1 «Ice».

Cluster 2 contains 10 shampoos, which are characterized by a relatively low price, low consumer ratings and the content of substances dangerous to the human body at a level slightly below average. The consumer should pay attention to the shampoo of this cluster, because they are pleasantly different in price from the shampoos of the third cluster. And although, according to subjective assessments of consumers, show the worst result, but the number of harmful additives in their composition is on average slightly higher than in shampoos in cluster 3. Cluster 2 includes the following shampoos: Pirana, shampoo-balm «White Flowers», flower lotus»; Clear Vita Abe, detoxifying shampoo «Moisturizing against dandruff»; Garnier, Ginger Recovery Shampoo for exhausted and very thin hair; Pantene, shampoo «Merger with nature. Cleansing and nutrition "; Effa Pharms, shampoo for sensual scalp; Gliss Cur, shampoo with Monoi flower extract «Summer Season»; Green pharmacy, shampoo «Birch 
buds and castor oil»; Soyoss, shampoo for dry and lifeless hair; Organic Life, argan shampoo «Pineapple», for oily hair; Pharma Goup, shampoo «Restoration of severely damaged hair».

The third cluster includes 9 shampoos, which are characterized by a fairly high price, the best consumer feedback, as well as the lowest content in their composition of substances dangerous to the human body. Shampoos of this cluster can be recommended for use first of all. These include: Shakylab, a sulfate-free shampoo for normal hair; Pirana, herbal shampoo «Nettle»; Kallos Cosmetics, shampoo for normal and oily hair; «Vitex», hair shampoo «Silky and shiny curls», children's; Aasha, Ayurvedic shampoo for colored hair; Amway, 2-in-1 conditioner shampoo; «Yaka», shampoo-balm for hair restoration with wheat proteins and "Yaka» essential oils; Brelil, shampoo for smoothing hair; Liv Delano, shampoo for oily hair «Freshness and comfort».

\section{CONCLUSIONS}

According to the results of the study, a number of conclusions were made. The modern market of shampoos is widely represented by the products that contain a significant amount of substances known for their dangerous properties to human health. Such hazardous substances include: detergents, silicones, preservatives (in particular, such varieties as parabens), dyes (primarily of synthetic origin), synthetic fragrances (phthalates), etc. All these substances are not only toxic, but mostly they have allergenic, carcinogenic or other adverse effects on the human body, which during prolonged use fall for their intended purpose. Different names of shampoos differ significantly in the number of hazardous substances that are part of them. Up to 13 of such substances were detected.

Taking into account the number of substances dangerous to human health in the hygiene product, the price of the product and the assessment of product quality provided by consumers, among the 25 items of shampoos were identified those most recommended for consumption: Shakylab, sulfate-free for normal hair; Pirana, Nettles; Kallos Cosmetics, for normal and oily hair; "Vitex», «Silky and shiny curls», children's; Aasha, for colored hair; Ammway, 2-in-1; Yaka, with wheat proteins and Yaka essential oils; Brelil, for smoothing hair; Liv Delano, «Freshness and Comfort».

\section{REFERENCES}

1. Peshuk, L.V., Bavika, L.I., Demidov, I.M. (2007). Tekhnolohiia parfumerno-kosmetychnykh produktiv: navchalnyi posibnyk dlia studentiv [Technology of perfumery and cosmetics: textbook for students]. Kyiv: Tsentr uchbovoi literatury, 376 p. [in Ukrainian].

2. Altyieva, O.V, Batychenko, N.V. (2002). Tendentsiia rozvytku potreb u myinykh kosmetyko-hihiienichnykh zasobakh $\mathrm{v}$ Ukraini [The trend of development of needs in detergents and cosmetics in Ukraine]. Torhivlia i rynok Ukrainy - Trade and market of Ukraine, no. 13, vol. 2, pp. 12-20. Donetsk: DonDUET [in Ukrainian].

3. Krivova, A.Yu., Paronyan, V.Kh. (2009). Tekhnologiya proizvodstva parfyumerno-kosmeticheskikh produktov [Technology of production of perfumery and cosmetic products]. Moscow: DeLi print, $668 \mathrm{p}$. [in Russian].

4. Yakovleva, L.A., Kutakova, G.S. (2001). Tovarovedenie parfyumerno-kosmeticheskikh tovarov: uchebnik dlya vuzov [Commodity research of perfumery and cosmetic products: a textbook for universities]. Sankt-Peterburg: Lan, 256 p. [in Russian].

5. Bukreieva, N.P. (2011). Vykorystannia importnoi syrovyny $v$ parfumernokosmetychnii promyslovosti: oblikovo-kontrolni aspekty [The use of imported raw materials in the perfume and cosmetics industry: accounting and control aspects]. (Extended abstract of Candidate's thesis). Kyiv National Economic University named after Vadym Hetman. Kyiv, 22 p. [in Ukrainian].

6. Horodetska, I.V. (2015). Anhliiskomovnyi reklamnyi tekst kosmetychnykh zasobiv: struktura, sementyka, prahmatyka [English-language advertising text of cosmetics: structure, semantics, pragmatics]. (Candidate's thesis). Yuriy Fedkovych Chernivtsi National University. Chernivtsi, 203 p. [in Ukrainian].

7. Bashura, O.H., Polovko, N.P., Kovaleva, T.N., Peresadko, I.H. (2009) Tekhnolohiia kosmetychnykh ta parfumernykh zasobiv: navch. pos. dlia stud. farmats. cpets. vyshch. navch. zakladiv [Technology of cosmetics and perfumes: a textbook for students of pharmaceutical specialties of higher educational institutions]. Vinnytsia: Nova knyha, 256 p. [in Ukrainian].

8. Baitsar, R.I., Kordiiaka, Yu.M. (2013). Napriamky rozvytku vyrobnytstva shampuniv ta zabezpechennia yikh yakosti [Directions of development of shampoo production and ensuring their quality]. Formation and evaluation of the range, properties and quality of non-food products '13: Materialy 1-yi Mizhnarodnoyi naukovo-praktychnoyi konferentsiyi (Lviv, 22 lystopada $2013 \mathrm{r}$.) - Proceedings of the First International Scientific and Practical Conference. (pp. 33-40). Lviv: Komertsiina Akademiia [in Ukrainian]. 
9. Belikov, O.Ye., Puchkova, T.V. (2003). Konservanty v kosmetike i sredstvakh gigieny [Preservatives in cosmetics and hygiene products]. Moscow: Shkola kosmeticheskikh khimikov, 245 p. [in Russian].

10. Baitsar, R.I. (2015) Ultrafioletovi filtry u kosmetychnii produktsii [Ultraviolet filters in cosmetic products]. Measurement, control and diagnostics in technical systems '15: Materialy III Mizhnarodnoyi naukovo-praktychnoyi konferentsiyi (Vinnytsia, zhovten 2015 r.) - Proceedings of the Third International Scientific and Practical Conference. (pp. 37-40). Vinnytsia [in Ukrainian].

11. Baitsar, R.I. (2016). Rozvytok metodiv vyprobuvan kosmetychnykh zasobiv [Development of testing methods for cosmetics]. "Technical Using of Measurement - 2016»: Materialy Vseukr. nauk.-tekhn. konf. molodykh vchenykh u tsaryni metrolohii (Kyiv, 1-5 liutoho, 2016 r.) - Proceedings of the AllUkrainian scientific and technical conf. young scientists in the field of metrology. (pp. 53-56). Kyiv [in Ukrainian].

12. Shampuni ta pinomyini zasoby. Metod vyznachennia zahalnoi zabrudnenosti mikroorhanizmamy [Shampoos and foaming agents. Method for determining the total contamination by microorganisms]. (1996). DSTU 3438-96 (GOST 30468-97) from 01th July 1996. Kyiv: Derzhspozhyvstandart Ukrainy, 25 p. (National standard of Ukraine) [in Ukrainian].

13. Kordiiaka, Yu.M., Mikhalieva, M.S., Baitsar, R.I. (2015). Normovani pokaznyky yakosti pinomyinykh kosmetychnykh zasobiv, shcho zabezpechuiut pokrashchennia yikh reolohichnykh vlastyvostei [Normalized quality indicators of foam cosmetics that improve their rheological properties]. Visnyk Natsionalnoho universytetu "Lvivska politekhnika» Vymiriuvalna tekhnika ta metrolohiia - Bulletin of Lviv Polytechnic National University Measuring equipment and metrology, 75, 107-110 [in Ukrainian].

14. Kordiiaka, Yu.M., Mikhalieva, M.S., Baitsar, R.I. (2016). Sposib shvydkoho kontroliu antyseptychnykh rechovyn u pinomyinykh kosmetychnykh zasobakh [The method of rapid control of antiseptic substances in foam cosmetics]. Control and management in complex systems (CMCS-2016): Materialy XIII Mizhnarodnoyi konferentsiyi (Vinnytsia, 3-6 zhovtnia, 2016 r.) - Proceedings of the Thirteenth International Conference. (pp. 210-212). Vinnytsia [in Ukrainian].

15. Zhuk, O.V. (2015). Rozrobka skladu ta tekhnolohii dytiachoho pinomyinoho zasobu [Development of the composition and technology of children's foam]. (Candidate's thesis). National University of Pharmacy. Kharkiv, 156 p. [in Ukrainian].

\title{
ОЦІНКА СКЛАДУ ДЕЯКИХ ЗАСОБІВ ОСОБИСТОЇ ГІГІСНИ (НА ПРИКЛАДІ ШАМПУНІВ) ЩОДО НЕГАТИВНОГО ВПЛИВУ НА ОРГАНІЗМ ЛЮДИНИ
}

\author{
Н.В. Грабко \\ старший викладач кафедри екології та охорони довкілля \\ Одеський державний екологічний університет \\ (м. Одеса, Україна) \\ e-mail: grabkonatalyavikt@gmail.com; \\ ORCID: https://orcid.org/0000-0003-1412-5683
}

Г.М. Вовкодав кандидат хімічних наук, доцент кафредри екології та охорони довкілля Одеський державний екологічний університет (м. Одеса, Україна) e-mail: galinakoltykova258@gmail.com; ORCID: https://orcid.org/0000-0002-4953-9491

А.-В. В. Крутій магістр кафедри екології та охорони довкілля Одеський державний екологічний університет

(м. Одеса, Україна) e-mail: violettakru9@gmail.com;

ORCID: https://orcid.org/0000-0002-2740-5281

У складі всіх шампунів містятвся різні шкідливі компоненти, які, накопичуючисъ у організмі, можуть завдати шкоди здоров'ю людини загалом. Вони можуть спричинити алергію, провокувати старіння, призводити до нервових порушень $і$ серизево-судинних захворюванъ. Але, незважаючи на цее, ијі речовини не можна виключити зі складу сучасних шампунів, тому шо без них косметичні засоби втратять свої властивості. Правильний вибір шампуню допоможе знизити ризик шкідливого впливу, але для иъого необхідно знати, наскільки негативно може впливати на здоров'я той чи інший інгредієнт.

Метою роботи є виділення найбільш безпечних груп шампунів із погляу вмісту в їх складі небезпечних для здоров'я людини речовин. Об'єктом роботи є шалпуні (25 найменуванъ). Предметом дослідження є опис найбільш безпечних для споживача груп шампунів із врахуванням їх иіни 
й суб'єктивної оиінки споживачів. Вихідними даними послужила інбормачія про склад кожного із шампунів, вказана виробником на товарній упаковиі кожного дослідженого гігієнічного засобу. Піә час проведення дослідження використовувалися порівняльно-описові, грабічні, а також статистичні (метод $K$-середніх кластерного аналізу) методи обробки й надання інбормаиї. Результати роботи мають практичне значення, оскільки являють собою рекомендаиї для споживача, ијо полягають у необхідності вибору засобів особистої гігієни (иампуню) серед запропонованих переліків найбезпечніших зразків із найменшою ијіною й найкрашими споживчими властивостяли. У таких переліках мають бути безпосереднъо зачікавлені споживачі, які дбають про стан свого здоров'я.

Ключові слова: шампунъ, сульбати, консерванти, парабени, фбталати, алергенні речовини.

\section{ЛITEPАТУРА}

1. Пешук Л.В., Бавіка Л.І., Демідов I.М. Технологія парфумерно-косметичних продуктів: навч. пос. для студ. К.: Центр учбової літератури, 2007. 376 с.

2. Алтиєва О.В, Батиченко Н.В. Тенденція розвитку потреб у мийних косметико-гігієнічних засобах в Україні. Торгівля і ринок України. Донецьк: ДонДУЕТ, 2002. Т. 2, вип. 13. С. 12-20.

3. Кривова А.Ю., Паронян В.Х. Технология производства парфюмерно-косметических продуктов. М.: ДеЛи принт, 2009. 668 с.

4. Яковлева Л.А., Кутакова Г.С. Товароведение парфюмерно-косметических товаров: учеб. для вуз. СПб.: Издательство «Лань», 2001. 256 с.

5. Букреєва Н.П. Використання імпортної сировини в парфумернокосметичній промисловості: обліковоконтрольні аспекти: автореф. дис. ... канд. екон. наук: 08.00.09 / Київський національний економічний університет імені Вадима Гетьмана. Київ, 2011. 22 с.

6. Городецька I.В. Англійськомовний рекламний текст косметичних засобів: структура, сементика, прагматика: дис. ... канд. фріл. наук: 10.02.04 / Чернівецький національний університет імені Юрія Федьковича. Чернівці, 2015. 203 с.

7. Башура О.Г., Половко Н.П., Ковалева Т.Н., Пересадько І.Г. Технологія косметичних та парфумерних засобів: навч. пос. для студ. фрармац. спец. вищ. навч. закладів. Вінниця: Нова книга, 2009. 256 с.

8. Байцар P.I., Кордіяка Ю.М. Напрямки розвитку виробництва шампунів та забезпечення їх якості. Форлування $і$ оиінювання асортименту, властивостей та якості непродовольчих товарів: Матеріали 1-ї Міжнар. наук.-практ. конф. (Лъвів, 22 листопада 2013 р.). Л., 2013. С. 37-40.

9. Беликов О.Е., Пучкова Т.В. Консерванты в косметике и средствах гигиены. М.: Школа косметических химиков, 2003. 245 с.

10. Байцар P.I. Ультрафріолетові фрільтри у косметичній продукції. Вимірювання, контроль та діагностика у технічних системах: Матеріали III Міжнар. наук. конб. (Вінниця, жовтенъ 2015 р.). B., 2015. C. 37-40.

11. Байцар Р.І. Розвиток методів випробувань косметичних засобів. «Technical Using of Measurement2016 »: Матеріали Всеукр. наук.-техн. конф. молодих вчених у царині метрології. (Київ, 1-5 лютого, 2016 p.). К., 2016. C. 53-56.

12. ДСТУ 3438-96 (ГОСТ 30468-97). Шампуні та піномийні засоби. Метод визначення загальної забрудненості мікроорганізмами. [Чинний від 1996-07-01]. К.: Держспоживстандарт України, 1996. 25 с. (Національний стандарт України).

13. Кордіяка Ю.М., Міхалєва М.С., Байцар Р.І. Нормовані показники якості піномийних косметичних засобів, що забезпечують покращення їх реологічних властивостей. Вісник Національного університету "Лъвівсъка політехніка» Вимірювальна техніка та метрологія. 2015. Вип. 75. С. $107-110$.

14. Кордіяка Ю.М., Міхалєва М.С., Байцар Р.І. Спосіб швидкого контролю антисептичних речовин у піномийних косметичних засобах. Контроль $і$ управління у складних системах (КУСС-2016): Матеріали XIII Міжнар. конф. (Вінниця, 3-6 жовтня, 2016 р.). В., 2016. С. 210-212.

15. Жук О.В Розробка складу та технології дитячого піномийного засобу: дис. ... канд. фрарм. наук: 15.00.01 / Національний фармацевтичний університет. Харків, 2015. 156 с.

\section{ВІДОМОСТІ ПРО АВТОРІВ}

Грабко Наталія Вікторівна, старший викладач кафедри екології та охорони довкілля, Одеський державний екологічний університет (вул. Львівська, 15, м. Одеса, Україна, 65016; e-mail: grabkonatalyavikt @gmail.com; ORCID: https://orcid.org/0000-0003-1412-5683)

Вовкодав Галина Миколаївна, кандидат хімічних наук, доцент кафедри екології та охорони довкілля, Одеський державний екологічний університет (вул. Львівська, 15, м. Одеса, Україна, 65016; e-mail: galinakoltykova258@gmail.com; ORCID: https://orcid.org/0000-0002-4953-9491)

Крутій Анна-Віолета, магістр кафедри екології та охорони довкілля, Одеський державний екологічний університет (вул. Львівська, 15, м. Одеса, Україна, 65016; e-mail: violettakru9@ukr. net; ORCID: https://orcid.org/0000-0002-2740-5281) 